\title{
Proto-fascism and State impunity in Majoritarian India: An Interview with Teesta Setalvad
}

\author{
Oishik Sircar ${ }^{1}$ \\ Published online: 21 July 2020 \\ (c) O.P. Jindal Global University (JGU) 2020
}

\begin{abstract}
This interview with Teesta Setalvad was conducted in the wake of the February 2020 anti-Muslim violence in North East Delhi. Drawing on her vast experience as a human rights activist, journalist, and peace educator, Setalvad's responses map the continuum - across years, anti-minority pogroms and ruling parties with divergent ideologies - of the cultures of hate, and the practices of state repression and impunity in a proto-fascist India. Setalvad offers an interrogation of the ideology of the Hindu right, delves into the historical trajectories of the rise of the Rashtriya Swayamsevak Sangh (RSS) and the Bharatiya Janata Party (BJP). She also charts the repeating patterns of police and media complicity in fomenting anti-minority hate and critically analyses the contradictory role of the criminal law and the Constitution of India in both enabling and resisting communal violence. In conclusion, she offers hopeful strategies for keeping alive the promise of secularism.
\end{abstract}

Keywords State impunity · Hindutva · Gujarat $2002 \cdot$ Pogrom · Genocide

\section{Introduction}

The cover of Teesta Setalvad's memoir - Foot Soldier of the Constitution - features a photograph of her looking directly into the eyes of the reader. ${ }^{1}$ Her face is partly lit and lightly silhouetted, her eyes simultaneously conveying an invitation and a provocation. One might use words like determination, courage and fortitude to describe the expression on her face - as the blurb on the back cover of the book does. For me though, the play of light and shadow more appositely gives her face a Stoic aura ${ }^{2}$ — not sentimental

\footnotetext{
${ }^{1}$ Teesta Setalvad, Foot Soldier of the Constitution: A Memoir (LeftWord Books 2017). I was not able to find a mention of who the photographer is in the book.

2 Brian D. Earp, 'Against Mourning' (Aeon, 21 August 2018). https://aeon.co/essays/do-not-weep-foryour-dead-how-to-mourn-as-the-stoics-did. Accessed 19 June 2020.

Oishik Sircar

osircar@jgu.edu.in

1 O.P. Jindal Global University, Sonipat, India
} 
but resilient in the face of both the political and personal struggles and tribulations that have shaped what she calls her 'larger conviction - the need for India and our institutions to be just. ${ }^{3}$ This was a simple yet profoundly powerful conviction in 2017, when the book was published - three years into Narendra Modi's first term as Prime Minister of India - and continues to remain so in 2020, given the assault that Hindutva ideology has been wreaking on India's democratic institutions, minority and dissenting citizens, and its secular fabric since the beginning of his second term in 2019.

The performance and embodiment of this conviction in times of despair require 'pessimism of the intellect, optimism of the will.' Attributed to the Italian Marxist Antonio Gramsci - who had borrowed these words from Romain Rolland ${ }^{4}$ — the phrase describes 'the (seemingly contradictory) coexistence of a realistic description of the status quo, on the one hand, and a genuine commitment to the possibility of transforming reality, on the other. ${ }^{5}$ Setalvad's life's work as a journalist, activist, human rights defender, and peace educator, has been a testament to such a process of ethical self-making in a public life that has been rife with threats, intimidation and harassment from the ruling establishment for her dogged pursuit of justice in solidarity with the victims and survivors of the 2002 anti-Muslim pogrom in Gujarat. ${ }^{6}$

I met Teesta for the first time very briefly at the Shah Alam dargah in Ahmedabad - that was turned into a refugee camp for displaced Muslims in the wake of the pogrom - when I visited Gujarat in March 2002 as part of a fact-finding team of lawyers brought together by the South Asia Human Rights Documentation Centre in Delhi. She was one of the first journalists to arrive in Gujarat to start collecting testimonies of victim-survivors and had already begun coordinating relief and legal aid over the telephone from Bombay prior to that. Our team wanted to get a lay of the land before we started collecting testimonies and also to ensure that we do not end up repeating what was already underway. Teesta's sound advice was particularly crucial in helping us limit the scope of our work there.

With her colleague and partner Javed Anand, Teesta was the editor of the magazine Communalism Combat that they founded in 1993 in response to the anti-Muslim violence in Bombay that spread after the demolition of the Babri Masjid in Ayodhya on 6 December 1992. For their March-April 2002 edition, the magazine brought out a full issue titled 'Genocide: Gujarat 2002', covering in detail the timeline of the unfolding of the pogrom, victim testimonies, photographs, reports on the violence across several districts in Gujarat, and the role that state inaction and police connivance played in enabling the mobs that systematically targeted Muslim lives, homes, and livelihoods. ${ }^{7}$

\footnotetext{
3 Setalvad (n 1) 9.

4 Rolland's original composition of the phrase, as it appeared in Gramsci's Selections from the Prison Notebooks was: 'Pessimism of the intelligence' and 'optimism of the will.' Antonio Gramsci, Selections from the Prison Notebooks (tr. Quintin Hoare and Geoffrey Nowell Smith) (1st edn, International Publishers 1992) 175.

5 Francesca Antonini, 'Pessimism of the Intellect, Optimism of the Will: Gramsci's Political Thought in the Last Miscellaneous Notebooks' (2019) 31 (1) Rethinking Marxism 42, 43.

6 Anupama Karakam, 'Targeting an Activist' (Frontline, 22 June 2018). https://frontline.thehindu.com/ the-nation/article24208006.ece. Accessed 19 June 2020.

7 Javed Anand and Teesta Setalvad, 'Genocide: Gujarat 2002' (2002) 8 (77-78) Communalism Combat.
} 
It remains a landmark archival document that demonstrates what journalistic integrity, perseverance and acumen can achieve even without adequate resources. The issue is also important for having used the word 'genocide' — to draw on its legal and rhetorical force - to describe what happened in Gujarat and to displace the woefully inadequate expression in the word 'riot' that was being and is still used by most media outlets to refer to Gujarat 2002. At a time when there was no social media, the use of the word genocide to describe the violence - even if one argues against its appropriateness on technical grounds - was also part of an effective advocacy strategy to mobilise global attention and condemnation.

Teesta was also instrumental, through her organisation Citizens for Justice and Peace (CJP) — founded in 2002 with Javed Anand to provide legal aid to the victims of the Gujarat pogrom - in setting up the Concerned Citizens Tribunal (CCT), headed by the then retired judge of the Supreme Court of India, Justice Krishna Iyer and seven other members, including eminent judges, lawyers, activists, and academics. The CCT brought out a detailed two-volume report titled Crime Against Humanity: An Inquiry into the Carnage in Gujarat that is one of the most comprehensive and harrowing records of the pogrom. ${ }^{8}$ Teesta was the public face of CJP in its support to Zahira Sheikh, the star witness in the Best Bakery case, till Zahira turned hostile and accused CJP of manipulating her to lie - which was proven to be false. A major victory for CJP in the Best Bakery trial was in making the Supreme Court order that the case be shifted to Bombay to ensure a fair trial that was not vitiated by the prejudicial political atmosphere in Gujarat that had led to both the Vadodara Sessions and Gujarat High Courts acquitting the accused. ${ }^{9}$

Through CJP, Teesta has been supporting Zakia Jafri, the widow of the politician Ehsan Jafri, who was brutally murdered during the pogrom in Ahmedabad. Zakia Jafri's 'protest petition' had assembled crucial evidence to challenge the decision of the Supreme Court appointed Special Investigation Team (SIT) that exonerated Narendra Modi, the Chief Minister of Gujarat in 2002, for his chain of command responsibility as head of the state for both acts of omission and commission. ${ }^{10}$ In the run-up to the appeal against the SIT, the Modi government, which was already in power in Delhi, began intimidating and harassing her and Javed, who 'faced court proceedings on fabricated charges of embezzlement, misuse of funds and "antinational propaganda". 11 They have since averted arrest based on anticipatory bail being granted by the Bombay High Court and the Gujarat High Court. ${ }^{12}$

\footnotetext{
${ }^{8}$ CCT, Crime Against Humanity: An Inquiry into the Carnage in Gujarat (2002).

9 Annapurna Waghray, 'The Best Bakery Case: Zahira Habibulla H. Sheikh and Another vs State of Gujarat and Others' (2006) 2 Journal of Islamic State Practices in International Law 17.

10 Teesta Setalvad, 'The Importance of Zakia Jafri's Protest Petition' (2013) 48 (21) Economic and Political Weekly 10.

11 Front Line Defenders, Stop the killing of Human Rights Defenders: Annual Report 2016 (International Foundation for the Protection of Human Rights Defenders 2016) 14.

12 Rahi Gaikwad, 'Bombay High Court grants anticipatory bail to Teesta Setalvad' (The Hindu, 11 August 2016). https://www.thehindu.com/news/national/bombay-high-court-grants-anticipatory-bail-toteesta-setalvad/article7526189.ece. Accessed 19 June 2020; CJP, 'Gujarat High Court granting bail to Teesta Setalvad is a huge victory: Citizens for Justice and Peace' (The Leaflet, 12 February 2019) http:// theleaflet.in/gujarat-high-court-granting-anticipatory-bail-to-teesta-setalvad-is-a-huge-victory-citizensfor-justice-and-peace/. Accessed 19 June 2020.
} 
In 2010, I invited Teesta to the Jindal Global Law School (JGLS) for a workshop titled 'The Perversity of National Security' that I had convened. Because of the threats to her life that she was constantly receiving, Teesta used to move around with two armed bodyguards, but during the workshop, she had asked them to remain outside the room where the event was held. The United Progressive Alliance (UPA) government was in power at that time with Operation Green hunt the state's armed offensive against Naxalite guerrillas — already underway. ${ }^{13}$ The operation was an alibi for enabling the Indian state to acquire land - protected by the Naxalites - by displacing Adivasi populations for the setting up of coal and aluminium mines by huge multinational corporations. The Naxalites were hyperbolically called India's 'gravest internal security threat' by the then Prime Minister Manmohan Singh. This declaration justified the state's armed response which also used the propagandist rhetoric of liberating Adivasis from Naxal oppression. ${ }^{14}$

At that time Dr. Binayak Sen, a public health and human rights activist with the People's Union of Civil Liberties was in prison under trumped-up charges of being a Maoist accomplice, convicted for the crimes of sedition and conspiracy to wage war against the state under the Indian Penal Code, 1860 (IPC) and two draconian special security legislations: the Chhattisgarh Special Public Security Act, 2005, and the Unlawful Activities (Prevention) Act, 1967 (UAPA). ${ }^{15}$ The convictions in the Best Bakery retrial in the Court of Sessions of Greater Bombay had already been delivered by that time. In February 2006, the court convicted nine people. In March 2006, the Supreme Court convicted Zahira Sheikh of perjury, vindicating Teesta and CJP's position against the accusations that they had bribed Zahira to lie in court. In 2010, she was actively involved in pursuing other cases related to the Gujarat pogrom, including the legal support CJP extended to Zakia Jafri.

I met Teesta again in 2017 when she was visiting JGLS to teach a course on 'Communal Conflict and Courts in India'. Her memoir had just been published, and armed bodyguards did not accompany her. Did that suggest a retreat of the threats or the emergence of a state that had started protecting rights of dissenters? Far from it. We were three years into the Bharatiya Janata Party's rule in India with Modi at the helm. The signs of what was being done to turn India into a Hindu rashtra (nation) were loud and clear. There was an outsourced non-state army of Hindutva's foot soldiers who were fearlessly advancing the state's proto-fascist agenda with the state offering ideological approval. The lynching of Muslims and Dalits, the murders of rationalists, secularists and dissenters, the intimidation of student activists, and the throttling of academic freedom of progressive voices in Indian universities, among others, were gaining ground and popular support.

\footnotetext{
13 Radha D'Souza, 'Sandwich Theory and Operation Green Hunt' (MRonline, 17 December 2009). https ://mronline.org/2009/12/17/sandwich-theory-and-operation-green-hunt/. Accessed 19 June 2020.

14 Alpa Shah, Nightmarch: Among India's Revolutionary Guerrillas (University of Chicago Press 2019) xiv.

15 Ilina Sen, Inside Chhattisgarh: A Political Memoir (Penguin 2014).
} 
This interview with Teesta Setalvad was conducted on email through February and March in 2020. ${ }^{16}$ It began at a time when the anti-Muslim pogrom in North East Delhi had barely abated, and the announcement of the all-India lockdown for Covid19 led to the anti-Citizenship (Amendment) Act, 2019 (CAA) protesters at Shaheen Bagh in Delhi suspending their sit-in. ${ }^{17}$ Through the period of our email exchange, academic Anand Teltumbde and activist Gautam Navlakha were arrested under the new and more draconian avatar of the UAPA. The police followed a modus operandi very similar to what was done to Binayak Sen. ${ }^{18}$ Several other activists and human rights lawyers were already in jail on unbailable charges under the UAPA. As our conversation progressed over email, more arrests were carried out targeting student activists who were involved in anti-CAA protests - deeming the practice of the fundamental right to freedom of speech and expression as a 'terrorist act'. ${ }^{19}$ Of course, the communication siege of Kashmir, already under political lockdown since the abrogation of Article 350 in August 2019, continued as well with repeated instances of human rights abuses by the state, now specially enabled under the cover of the Covid-19 lockdown. ${ }^{20}$

Teesta's responses to my questions help us map the continuum - across years, anti-minority pogroms and ruling parties with divergent ideologies - of the cultures of hate, and the practices of state repression and impunity in an India that has now embraced fascism with pride. She had noted presciently in her memoir: 'Slowly and surely what we are witnessing is a refashioning of the Indian Republic. ${ }^{21}$ Even in these unprecedented times of the Covid-19 pandemic, it has been business as usual for the repressive arms of the state, particularly the police as it has always been, and increasingly the judiciary which has mostly remained tacitly complicit in the state's excesses. ${ }^{22}$ The police's treatment of poor migrant workers and daily wage earners, ${ }^{23}$

\footnotetext{
${ }^{16}$ The text of the interview went through multiple rounds of editing where both Teesta and I revised our questions and answers, respectively. This was a particularly useful process because it helped bring an element of the conversational into the exchange. Both Teesta and I have annotated the text with references to key sources to maintain factual accuracy and argumentative integrity. The annotated references will help interested readers to follow-up on the positions and ideas presented.

${ }^{17}$ FE Online, 'Coronavirus: Shaheen Bagh protest cleared after 100 days amid lockdown in Delhi' (Financial Express, 24 March 2020). https://www.financialexpress.com/india-news/coronavirus-shaheenbagh-protest-cleared-after-100-days-amid-lockdown-in-delhi/1907407/. Accessed 19 June 2020.

${ }^{18}$ Nikita Khaitan, 'New Act UAPA: Absolute power to state' (Frontline, 25 October 2019). https://front line.thehindu.com/cover-story/article29618049.ece. Accessed 19 June 2020.

${ }^{19}$ Manisha Sethi, 'Delhi Riot Conspiracy Theory: Aim is to Make Every Muslim Guilty' (Outlook, 28 April 2020). https://www.outlookindia.com/website/story/delhi-riot-conspiracy-theory-aim-is-to-makeevery-muslim-guilty/351674. Accessed 19 June 2020.

${ }^{20}$ Omer Aijazi, 'India uses coronavirus pandemic to exploit human rights in Kashmir' (The Conversation, 8 May 2020). https://theconversation.com/india-uses-coronavirus-pandemic-to-exploit-human-right s-in-kashmir-137682. Accessed 19 June 2020.

${ }^{21}$ Setalvad (n 1) 215.

${ }^{22}$ Mihir Desai, 'Covid-19 and the Indian Supreme Court' (CJP, 30 May 2020). https://cjp.org.in/covid -19-and-the-indian-supreme-court/. Accessed 19 June 2020.

${ }^{23}$ Rajulapudi Srinivas, 'Covid-19 lockdown: Police beat up migrant workers, send them to shelter homes later' (The Hindu, 16 May 2020). https://www.thehindu.com/news/cities/Vijayawada/covid -19-lockdown-police-beat-up-migrant-workers-send-them-to-shelter-homes-later/article31599485.ece. Accessed 19 June 2020.
} 
the continuing silencing of the dissident voices of students and activists speaking up for democracy and the Constitution, ${ }^{24}$ and the collective vilification of Muslims as 'Corona jihadists', ${ }^{25}$ are reflective of the ordinary depravities of a majoritarian state that have attained the status of normalised common sense under extraordinary conditions. 'Where, then, will resistance emerge?' she had asked in the closing pages of her memoir. ${ }^{26}$ Clearly, in alignment with the Gramsci maxim, Teesta's responses in this interview demonstrate how she keeps alive the optimism of her will and her commitment to justice, with Stoic calmness, even in these grim, tragic, hateful, and pessimistic times. $^{27}$

\section{Interview}

Oishik Sircar (OS): There's a line in your essay 'When Guardians Betray: The Role of the Police in Gujarat', which sounds cruelly prescient when thinking about Delhi 2020. 'Gujarat 2002', you write, 'provides horrific proof, if any were still needed, of the systemic infusion of hate politics in the minds of some police officials from the top echelons who are now wedded to principles that are hostile to the rule of law. 28 Do you think the matter of police complicity is one that is systemic irrespective of the ideology of the ruling dispensation or does political ideology play a motivating role behind the conduct of the police in aiding the violence in question?

Teesta Setalvad (TS): There are two distinct aspects to this question. I will, therefore, divide my answer into two parts. The first relates to the fact that, institutionally, the Indian police has not been insulated (through autonomy and independence) from the government of the day, the executive. Despite us being in the seventh decade of existence as a Republic, political parties (of different dispensations, and even the Left in Bengal or Kerala were/ are not an exception) have been loath to cede control over to the police. National Police Commission reports in the 1980s had recommended such autonomy, wherein the police would be accountable to the state legislatures and not the party in power. This continued subservient role that the police have to play hampers their independent constitutional functioning. During the Gujarat genocidal carnage of 2002, a handful of senior officers stood by their commitment to their constitutional oath and were made to suffer the vindictive wrath of

\footnotetext{
${ }^{24}$ Hanan Zaffar and Majid Alam, 'Despite a Lockdown, India is Cracking Down on Student Activists who Were a Part of Anti-CAA Protests' (Vice, 22 April 2020). https://www.vice.com/en_in/article/epgyx 7/india-cracks-down-on-anti-caa-students-despite-lockdown. Accessed 19 June 2020.

25 Hanna Ellis and Shaikh Azizur Rahman, 'Coronavirus conspiracy theories targeting Muslims spread in India' (The Guardian, 13 April 2020). https://www.theguardian.com/world/2020/apr/13/coronaviru s-conspiracy-theories-targeting-muslims-spread-in-india. Accessed 19 June 2020.

26 Setalvad (n 1) 215.

27 Oishik Sircar, 'Postcolonial Liberalism's Double Binds' (Critical Legal Thinking, 19 June 2020). https ://criticallegalthinking.com/2020/06/19/postcolonial-liberalisms-double-binds/. Accessed 22 June 2020.

28 Teesta Setalvad, 'When Guardians Betray: The Role of the Police in Gujarat' in Siddharth Varadarajan (ed), Gujarat: The Making of a Tragedy (Penguin 2002) 178.
} 
the government in power. To date, the central government tries to prevent payment of their pensions! ${ }^{29}$

Now, the second aspect of the question. Indian democracy has veered towards a dangerously majoritarian path where brute numbers and the majority vote displayed through a first-past-the-post election process has replaced the inherent constitutional fundamentals. We have witnessed this in the Indian state's response to the Sikh community (1984), Jammu and Kashmir (especially Kashmir, a Muslim majority region), and more specifically when it comes to containing the buildup and fallout of targeted communal violence. Hate speech (read inciteful speech that demonises sections of Indians) plays a significant role in the actual outbreak of such targeted violence. This is where ideology comes in. For close to a hundred years (since 1925), a specific ideology committed to a majoritarian theocratic Hindu state has been fostered through the systematic growth of the RSS. ${ }^{30}$ With deep and insidious sociocultural roots that reinforce a 3,000-year-old exclusivist caste system, this ideology that first targeted Mohandas Gandhi on 30 January 1947 has infiltrated the echelons of Indian institutions and democracy, all of them. ${ }^{31}$ Law enforcement and the Central Bureau of Investigation (CBI) are not immune from this insidious infiltration of a majoritarian ideology. The dangerous aspect of this ideology is - which is why some of us term it as proto-fascist - that it uses the democratic route to assume power and then wields power directly defying the constitutional ethos of equality and non-discrimination.

Since the 1980s, when a spate of pogromatic rounds of targeted killings took the lives of Indian minorities — Nellie (18 February 1983), Delhi (1984), HashimpuraMaliana (1987), ${ }^{32}$ Bhagalpur (1989), Bombay (1992-1993), and of course Gujarat (2002) - such an ideological influence has been documented, studied, analysed and commented upon, especially when it came to the conduct of men and women in uniform. If there had been institutional insulation from such a pernicious ideology, precious lives would have been saved because the police would have acted at the first sign of hate-filled provocations even before the mobs took over streets and localities. Senior police officials like K.F. Rustomjee, Padam Rosha, Julio Ribeiro, Satish

\footnotetext{
${ }^{29}$ RB Sreekumar, former Additional Director General of Police (Intelligence), Rahul Sharma, then SP Bhavnagar, and former senior Indian Police Service officers Rajnish Rai and Samiullah Ansari, are but a few examples. I have elaborated these in my work and this finds its place in the pending Zakia Ahsan Jafri's Special Leave Petition against the SIT, Union of India and State of Gujarat. See, Teesta Setalvad, 'Zakia Jafri's Case is a Reminder of How the Guilty of Gujarat Subverted the Law' (The Wire, 18 November 2018). https://thewire.in/rights/zakia-jafri-2002-gujarat-violence-supreme-court. Accessed 19 June 2020.

30 See A.G. Noorani, RSS: A Menace to India (LeftWord 2019).

31 See Dhirendra K. Jha, 'The Apostle of Hate' (The Caravan, 1 January 2020). https://caravanmagazine .in/reportage/historical-record-expose-lie-godse-left-rss. Accessed 19 June 2020.

32 Teesta Setalvad, 'Hashimpura a Blot and Shame, The Importance of Memory: Vibhuti Narain Rai' (Sabrang, 10 August 2016). https://sabrangindia.in/interview/hashimpura-blot-and-shame-importance -memory-vibhuti-narain-rai. Accessed 19 June 2020; Teesta Setalvad, "If our minorities lose faith in the Indian state, they will be easy prey for the ISI', (Sabrang, 1 August 2000). https://sabrangindia.in/article/ if-our-minorities-loose-faith-indian-state-they-will-be-easy-prey-isi. Accessed 19 June 2020.
} 
Sahney, apart from Vibhuti Narain Rai, ${ }^{33}$ and R.B. Sreekumar, ${ }^{34}$ have commented on this trend in their works.

OS: In your memoir Foot Soldier of the Constitution, you had developed the 'who cast the first stone' theory, where anti-Muslim violence in India is rationalised using the logic that 'every act of violence of the majority Hindu is an act of retaliation of the perennially and permanently barbaric Mussalmaan. ${ }^{35}$ Would you say that this theory holds true for Delhi 2020 as it did for Muzaffarnagar 2013 and Gujarat 2002?

TS: Yes, undoubtedly. I recall that my coinage of this phrase was resisted by many 'scholars'. Today, however, this has become a part of the usage even by experts who write on these issues. Essentially, I observed this in operation closely in Bombay post the Babri Masjid demolition in December 1992, and then during the second bout of violence in January 1993. Later, during the post-Godhra 2002 targeted violence against Gujarat's Muslims. What we see is this: for weeks and months preceding the first stone being cast, an overall social/ public atmosphere of hate speech is perpetrated through hate writing (newspapers, pamphlets) and hate speeches (public exhortations) against which - despite laws being in place - the police administration does not act. ${ }^{36}$ The higher judiciary too has been strangely complicit in not arresting this pernicious trend (no suo motu actions, no strong jurisprudence on inciteful speech). As a result of this institutional complacence (could even be influenced by majoritarianism), public acceptance of othering has grown. L.K. Advani's rath yatra (chariot procession) in 1990 was the single most powerful mechanism used by the supremacist right to exert its stranglehold on Indian politics. ${ }^{37}$ This trend legitimised terms like 'Muslim appeasement', 'pseudo-secularism' and the like. As the plans for the rath yatra loomed, hate pervaded the air, be it in railway compartments or cocktail parties in Delhi and Bombay. The 'mainstream media' played its part. My favourite example, strongly etched in memory, is of the India Today magazine - then the political magazine. A cover story titled 'The Lotus Blooms' with the glowing face of Advani legitimised the campaign even as newspapers like the Telegraph and Sunday Observer warned of the lurking dangers of this hateletting. Once the act was accomplished, and a 400-year-old mosque demolished in full public view, in broad daylight, the same magazine had a remorseful cover story condemning the act and praising individual and collective acts of secular heroism. That the RSS-BJP-VHP (Vishwa Hindu Parishad) combine's insidious crafting of a

\footnotetext{
33 Teesta Setalvad, 'An exclusive interview by Teesta Setalvad Co-editor Communalism Combat' (Sabrang, 21 March 2015). https://sabrangindia.in/theme/no-riot-can-last-more-24-hours-unless-state -wants-it-continue-vibhuti-narain-rai-ips-teesta. Accessed 19 June 2020.

34 RB Sreekumar, 'Days of Agony and Despair: former DGP, Gujarat, RB Sreekumar on How the Mob Ruled during the Gujarat Carnage of 2002' (Sabrang, 29 December 2015). https://sabrangindia.in/artic le/days-agony-and-despair-former-dgp-gujarat-rb-sreekumar-how-mob-ruled-during-gujarat-carnage. Accessed 19 June 2020.

35 Setalvad (n 1) 78.

36 'Fanning the Flames' (Communalism Combat, March-April 2002). https://www.sabrang.com/cc/archi ve/2002/marapril/faming.htm. Accessed 19 June 2020.

37 Kabir Agarwal, 'L.K. Advani, the Provocateur in Chief' (The Wire, 9 November 2019). https://thewi re.in/politics/the-provocateur-in-chief-l-k-advani. Accessed 19 June 2020.
} 
political campaign for the Ram janma bhoomi (the original birthplace of Lord Ram) movement was, in fact, a cover for not just the demolition of a mosque but the heralding and celebration of a majoritarian culture in Indian politics, was not remarked upon by the magazine.

This trend continued. In the build-up to 2002, for over six months but especially after the December 2001 dastardly attack on the Indian Parliament, ${ }^{38}$ hate pamphlets (authored proudly by the VHP or crafted 'anonymously' ${ }^{39}$ ) flooded Gujarat's villages and cities, exhorting economic and social boycott of Muslims, even the rape of Muslim women. ${ }^{40}$

Post-Gujarat 2002, though the country had a respite between 2004-2014, institutional corrective measures that were promised by the UPA in its Common Minimum Programme ${ }^{41}$ - mainly the Prevention of Communal and Targeted Violence (Access to Justice and Reparations) Bill, 2011 ${ }^{42}$ — were not carried out. There was huge resistance from the bureaucracy and the police. Towards the end of this decade, in 2013, as the legitimacy of the UPA regime dwindled, these proto-fascist forces were quick to take advantage. In the preceding years, an insidious term had gained legitimacy: 'love jihad'. ${ }^{43}$ Again it was just such an incident, individual and misconstrued, that was used to whip up hate against the minority. ${ }^{44}$ Hate speeches of the then Gujarat minister of state for Home Affairs, Amit Shah (he was even banned from campaigning by the Election Commission of the day) and Sanjiv Baliyan (later to get elevated as a reward in Prime Minister Narendra Modi's first cabinet in 2014) served to mobilise mobs and silence the minority. ${ }^{45}$ Courts were not proactive then

\footnotetext{
${ }^{38}$ For an analysis of the repressive state response in the wake of the attack see Arundhati Roy, The Hanging of Afzal Guru (Penguin 2016).

39 'Pamphlet Poison' (Communalism Combat, March-April 2002). https://www.sabrang.com/cc/archi ve/2002/marapril/pamphlet.htm. Accessed 19 June 2020.

${ }^{40}$ For a sampling of such pamphlets see Megha Kumar, Communalism and Sexual Violence: Ahmedabad since 1969 (Tulika 2017).

41 ICF, "'A huge compromise has been made by our so-called intellectuals." (Sabrang, 22 September 2016). https://sabrangindia.in/article/huge-compromise-has-been-made-our-so-called-intellectuals. Accessed 19 June 2020.

42 'Act now - Why the Communal and Targeted Violence Bill must be codified into law'

(Sabrang, 1 November 2011). https://sabrangindia.in/article/act-now-why-communal-and-targeted-viole nce-bill-must-be-codified-law. Accessed 19 June 2020.

43 See Charu Gupta, 'Hindu Women, Muslim Men: Love Jihad and Conversions' (2009) 44 (51) Economic and Political Weekly 13.

44 Subhashini Ali, 'In Amit Shah's Promise of Anti-Romeo Squads, A Large Threat' (NDTV, 7 February 2017). https://www.ndtv.com/opinion/in-amit-shahs-promise-of-anti-romeo-squads-a-large-threa t-1656622. Accessed 19 June 2020; Ram Puniyani, 'Muzaffarnagar + Dadri + Kairana = Jihad + Beef + "Hindu" Exodus = Hard Communalism = Votes' (The Citizen, 17 June 2016). https://www.thecitizen .in/index.php/en/NewsDetail/index/4/7990/Muzaffarnagar-Dadri--KairanaLove-JihadBeefHindu-Exodu sHard-CommunalismVotes. Accessed 19 June 2020.

45 Rupam Jain, 'Divisive politics return as Narendra Modi eyes UP election' (Livemint, 13 February, 2016). https://www.livemint.com/Politics/LP4yEop2QmrqXllo8vdabN/Divisive-politics-return-as-Naren dra-Modi-eyes-UP-elections.html. Accessed 19 June 2020.
} 
either, and we saw a pattern repeat itself this time with an additional tool: WhatsApp groups and messaging was used to create more hatred and othering of Muslims. ${ }^{46}$

But here's a rider: speeches by some 'leaders' among Muslims, belonging to the Bahujan Samaj Party, were played and replayed by commercial television channels selectively while the hate-letting of Baliyan and others were almost legitimised. Commercial television (unlike in Gujarat 2002 where Star TV, NDTV and Aaj Tak did some revelatory coverage at least) were by now almost entirely part of the chain indulging in bloodletting. ${ }^{47}$

By the time we come to Delhi 2020, much has happened and also changed. We are now six years into an out-and-out majoritarian regime wherein a spate of the lynching of Muslims have been celebrated even by ministers in the Modi cabinet ${ }^{48}$; where the utterings of senior ministers violate the law ${ }^{49}$; where the newly elected Chief Minister of India's most populous state, Uttar Pradesh, is unashamedly antiConstitution. Worse still, India's institutions, especially the higher judiciary, do not act. $^{50}$

It is in this overall atmosphere that, amazingly, a citizens' uprising against the all-out attempt to tamper with the Indian Constitution takes place, led by unlettered Muslim women. Before this, student leaders from Jamia Milia Islamia University joins Jawaharlal Nehru University and others who have been at the forefront of several protests over the past six years. ${ }^{51}$ The issue agitating the Muslim community is the direct existential threat posed by the CAA, the proposed National Population Register (NPR) and the National Register of Citizens (NRC). ${ }^{52}$ Moreover, it is Delhi's Shaheen Bagh, which captures the imagination of nationwide protesters, that becomes the single hate-letting motif of the supremacist right, including the party in power in Delhi. ${ }^{53}$ While this hate-letting dents the electoral victory of the Aam Aadmi Party in some constituencies, it still sweeps to power. Results are declared

\footnotetext{
${ }^{46}$ Mohammad Ali, 'The Rise of a Hindu Vigilante in the Age of WhatsApp and Modi' (Wired, 14 April 2020). https://www.wired.com/story/indias-frightening-descent-social-media-terror/. Accessed 19 June 2020.

47 Vindu Goel and Jeffrey Gettleman, 'Under Modi, India's Press Is Not So Free Anymore', (The New York Times, 2 April 2020). https://www.nytimes.com/2020/04/02/world/asia/modi-india-press-media .html. Accessed 19 June 2020.

48 SabrangIndia Staff, 'Look Who's Talking! Hate speech can't be free speech, says Jaitley'. (Sabrang, 26 February 2016). https://sabrangindia.in/article/look-whos-talking-hate-speech-cant-be-free-speec h-says-jaitley. Accessed 19 June 2020.

49 Anubhav Jaiswal, 'Disturbing Upward Increase: Communal Violence Under Modi Regime' (Sabrang, 6 July 2017). https://sabrangindia.in/article/disturbing-upward-increase-communal-violence-under-modiregime. Accessed 19 June 2020.

50 Saumya Saxena, 'CCourt'ing Hindu nationalism: law and the rise of modern Hindutva' (2018) 26 (4) Contemporary South Asia.

51 Rohit Azad, Janaki Nair, Mohinder Singh and Mallarika Sinha Roy (eds), What the Nation Really Needs to Know: The JNU Nationalism Lectures (HarperCollins Publishers 2016).

52 Our experience in Assam of the citizenship imbroglio has been an eye opener leading my organisation, CJP, into pro-active para-legal and legal activism. See updates on cjp.org.in/assam.

53 See Shuddhabrata Sengupta, 'The Garden of Freedom: Lessons that Shaheen Bagh teaches us about citizenship' (The Caravan, 2 February 2020). https://caravanmagazine.in/politics/lessons-that-shaheenbagh-teaches-us-about-citizenship. Accessed 19 June 2020.
} 
on 11 February 2020. Dissatisfied with this, frustrated even, violent bloodletting is unleashed by the likes of Kapil Mishra ${ }^{54}$ and Ragni Tiwari ${ }^{55}$ with the country's Home Minister too playing a crucial part. ${ }^{56}$

OS: There have always been debates about the most appropriate way to characterise mass anti-minority violence in India. The most commonly used term is 'riot' because it is the only form of collective violence that appears as a crime in the IPC. ${ }^{57}$ However, 'riot' seems woefully inadequate when we think of Gujarat, Muzaffarnagar or Delhi. Some of the other terms that have been used are 'genocide', 'pogrom' or 'crimes against humanity'. In fact, the Concerned Citizens Tribunal's reports on Gujarat 2002 - that you had convened - were titled 'Crime Against Humanity'. ${ }^{58}$ Do you think attending to this politics of naming is of significance in the legal struggles against demanding justice for mass violence? Which characterisation do you prefer and why?

TS: This is an important question. 'Riot' by its very definition suggests two or even three parties being involved in the conflict and undoubtedly, India has a long history of Hindu-Muslim 'riots' ${ }^{59}$ However, post 1980s when the Indian state started displaying a distinctly majoritarian character, the targeted violence against sections of our own people - made easy and possible because of the partisan role of the police - these bouts of targeted violence took the character of a pogrom. One of the lesser stated aspects of the 1983 Nellie anti-Muslim pogrom (some 2,500 marginalised, Bengali speaking Muslims were massacred in the space of six or seven hours and another 700 over the next few days; around 69 progressive activists affiliated to the Indian left were also targeted and killed when they criticised the Assam movement as being 'fascist') and the 1987 Hashimpura massacre is that the Indian army, not just the police, were involved in carrying out these brute and partisan acts. ${ }^{60}$

Both the Hashimpura massacre and the Bhagalpur killings of 1989 in the villages of Loghain and Chanderi - where in the space of 24 hours the dead were not just mass buried but cauliflower suddenly grown on the earth above! — were genocidal

\footnotetext{
54 CJP Team, 'Sign CJP's online petition to CJI Bobde to hold Kapil Mishra accountable for instigating the Delhi violence and prosecute him' (CJP, 26 February 2020). https://cjp.org.in/sign-cjps-online-petit ion-to-cji-bobde-to-hold-kapil-mishra-accountable-for-instigating-the-delhi-violence-and-prosecutehim/. Accessed 19 June 2020.

55 CJP Team, 'Ragni Tiwari incites violence: CJP files complaint against hate' (CJP, 4 March 2020). https://cjp.org.in/ragni-tiwari-incites-violencecjp-files-complaint-against-hate/. Accessed 19 June 2020.

56 Hanna Ellis-Petersen and Shaikh Azizur Rahman, 'Delhi's Muslims despair of justice after police implicated in riots' (The Guardian, 16 March 2020). https:/www.theguardian.com/world/2020/mar/16/ delhis-muslims-despair-justice-police-implicated-hindu-riots. Accessed 19 June 2020; Parijat, 'A mosque on fire, shops looted, people celebrating: My five hours in northeast Delhi' (The Caravan, 27 February 2020). https://caravanmagazine.in/conflict/delhi-violence-gokalpuri-mosque-fire. Accessed 19 June 2020.

57 Sections 146-148 of the Indian Penal Code, 1860.

58 CCT (n 8).

59 Sanjay Palshikar and Satish Despande (eds), Sectarian violence in India: Hindu-Muslim Conflict, 1966-2015 (Orient BlackSwan 2015).

60 Makiko Kimura, The Nellie Massacre of 1983: Agency of Rioters (SAGE Publications 2013); Vibhuti Narain Rai, Hashimpura: 22 May (Penguin 2016).
} 
pogroms. ${ }^{61}$ Full-blown genocidal carnage was visible in Gujarat 2002, where the Rome Statute of the International Criminal Court's definition of 'crimes against humanity' was met: the specific targeting, the social and economic boycott, and the sexual violence aimed at humiliation and annihilation of the culture and species of a minority. ${ }^{62} \mathrm{I}$, therefore, use the terms 'pogrom' or 'genocidal carnage' to depict and denote such violence. When resorting to them, I also painstakingly describe the elements that allow usage of these terms as there must be some rigour in both usage and description.

There is also a peculiar character of communalism and communal violence in India that has a historical angle. When we founded the magazine Communalism Combat in August 1993, we articulated it simply: 'We stand equidistant from both majority and minority communalism'. Of course, recognising that the majority communalism is more dangerous since it has the potential of changing the character of the state and minority communalism feeds into majority communalism, and in that sense, both are two sides of the same coin.

OS: There is a debate about whether it is appropriate to equate Hindutva ideology with fascism despite the documented evidence of how Italian Fascism and German Nazism inspired the founders of Hindutva. ${ }^{63}$ For example, during a speech at an anti-CAA protest in January this year, Ramachandra Guha said, 'Don't speak of Fascism, speak of the discriminatory legislation that the CAA represents. ${ }^{64}$ What are your thoughts on the relationship between Fascism and the Hindutva politics?

TS: With due respect, there is discrimination, and there is discrimination. The reason why some of us have clearly defined not just the Hindutva ideology but also their construct of the Indian nation and Indian society as proto-fascist is because of our painstaking involvement in observing, documenting and battling its emergence. Guha's facile dismissal appeals because it allows us first, not to confront the deep designs of this ideological and organisational onslaught and second because it trivialises what this discrimination and hate-letting are symptomatic off. Such sporadic responses of 'scholars' allows greater acceptability, even if unintended (of Hindutva).

One has to read Savarkar's own construct of the Hindu (not Indian) nation, M.S. Golwalkar's utterances in both 'We or our Nationhood Defined' and 'Bunch of Thoughts', ${ }^{65}$ and also the meticulous articulation of ideology and action in B.S. Moonje's ten-day diary after he met with Mussolini in a hotel in Rome to know and

\footnotetext{
61 Asghar Ali Engineer, 'Grim Tragedy of Bhagalpur Riots: Role of Police- Criminal Nexus' (1990) 25 (6) Economic and Political Weekly 305.

62 UN Office on Genocide Prevention and Responsibility to Protect, Crimes Against Humanity: Definitions. https://www.un.org/en/genocideprevention/crimes-against-humanity.shtml. Accessed 20 June 2020.

63 Marzia Casolari, 'Hindutva's Foreign Tie-Up in 1930s: Archival Evidence' (2000) 35 (4) Economic and Political Weekly 218.

64 Scroll Staff, "Not Fascism, speak of discriminatory CAA': Ramachandra Guha urges students to be careful with words' (Scroll.in, 9 January 2020). https://scroll.in/video/949279/not-fascism-speak-of-discr iminatory-caa-ramachandra-guha-urges-students-to-be-careful-with-words. Accessed 19 June 2020.

65 Teesta Setalvad, 'The ideology of the Rashtriya Swayamsevak Sangh (RSS) is both Hate-Ridden and Supremacist - Part 1' (Sabrang, 31 December 2015). https://sabrangindia.in/indepth/ideology-rashtriyaswayamsevak-sangh-rss-both-hate-ridden-and-supremacist-part-1. Accessed 19 June 2020.
} 
understand how the ideology of Hindutva will work. ${ }^{66}$ Alongside, we need to bear in mind the fact that the RSS had no role to play in the struggle for freedom against colonial rule. ${ }^{67}$ These utterances find tutored repetition in the thousands of neighbourhood shakhas (branches) of the RSS that have been the ingenuous tool of mass indoctrination and today have a visible stranglehold on Indian public discourse. ${ }^{68}$ So much so that the bits of history the current Prime Minister spouts are as a historical as what has been taught in the shakhas. ${ }^{69}$ The espousal of threat, intimidation and violence to ensure subjugation, the legitimisation of one messianic leader as the embodiment of deliverance and now, as we have seen, the systematic transfer of public resources to private capital, are reflections of a $21^{\text {st }}$ century proto-fascist state. Today, the funded BJP-RSS troll army on social media aids this proto-fascist state and a virtual battle against Indian democracy and the Constitution is being fought there, every day. ${ }^{70}$ The fact that there is a battle on at all, gives hope. The fact that brute state power is in the hands of an unscrupulous ideology is what gives rise to concern, as the costs of the ongoing battle just may be too high.

OS: As someone involved with the processes for seeking justice for victims and survivors of Gujarat 2002 - that began with supporting Zahira Sheikh during the Best Bakery trial, and continued as you pursued the protest petition for Zakia Jafri against the SIT's exoneration of Modi ${ }^{71}$ - you have firsthand experience of how the powers that be work to subvert the judicial process. We can think of the Vadodara Session Court's acquittals in the Best Bakery case, ${ }^{72}$ to Judge Loya's death while presiding over the Sohrabuddin Sheikh case, ${ }^{73}$ to Justice Muralidhar's recent transfer from the Delhi High Court after he was very critical of the Delhi Police's inaction during the North East Delhi violence against Muslims, ${ }^{74}$ as repeated instances of how the judiciary's independence has been thwarted. A similar and possibly much

\footnotetext{
66 Sabrangindia, 'Ahead of Pranab Mukherjee's impending speech at Nagpur, here's how the Sangh and its Pracharaks have Twisted Words of National Icons in the Past' (Sabrang, 7 June 2018). https://sabra ngindia.in/article/sangh-appropriation-icons-pranab-mukherjee-nagpur. Accessed 19 June 2020.

67 'Fact Check: The RSS Had No Role in India's Freedom Struggle' (Sabrang, 10 July 2019). https:// sabrangindia.in/article/fact-check-rss-had-no-role-indias-freedom-struggle-0. Accessed 19 June 2020.

68 See Aijaz Ahmad, 'Strictly Technical' (2020) 42 (6) London Review of Books.

69 Samanth Subramanian, 'How Hindu supremacists are tearing India apart' (The Guardian, 20 February 2020). https://www.theguardian.com/world/2020/feb/20/hindu-supremacists-nationalism-tearing-india -apart-modi-bjp-rss-jnu-attacks. Accessed 19 June 2020.

70 Ajaz Ashraf, 'Why are there so many Hindutva trolls?' (Scroll.in, 7 March 2016). https://scroll.in/artic le/804296/why-are-there-so-many-hindutva-trolls. Accessed 19 June 2020.

71 Harsh Mander, '2002 Gujarat riots: Why the 'clean chit' given to Narendra Modi does not absolve him' (Scroll.in, 23 April 2019). https://scroll.in/article/920939/2002-gujarat-riots-why-the-clean-chitgiven-to-narendra-modi-does-not-absolve-him. Accessed 19 June 2020.

72 'Best bakery Case Dateline' (CJP, 8 May 2017). https://cjp.org.in/bestfactfile/. Accessed 20 June 2020 .

73 The Wire Staff, 'Family Questions 'Suspicious Death' of Judge Who Heard Sohrabuddin Fake Encounter Case' (The Wire, 20 November 2017). https://thewire.in/politics/family-questions-suspicious -death-judge-heard-sohrabuddin-fake-encounter-case. Accessed 20 June 2020.

74 Scroll Staff, 'Delhi violence: HC judge who rapped police for inaction transferred to Punjab and Haryana High Court' (Scroll.in, 27 February 2020). https://scroll.in/latest/954459/delhi-violence-hc-judge -who-rapped-police-for-inaction-transferred-to-punjab-and-haryana-high-court. Accessed 20 June 2020.
} 
older trend can be seen when it comes to the pattern of anti-minority mass violence in India - from the 1983 massacre of Bengali Muslim immigrants from Bangladesh in Nellie, Assam to the anti-Sikh violence of 1984 in Delhi, to the anti-Muslim violence of 1992 in Bombay, the anti-Christian violence in Kandhamal in Orissa, to Gujarat 2002, Muzaffarnagar 2013, and now Delhi 2020, to name just a few. What sustains your faith in the justice delivery system when we know that the judiciary, like the police, is not insulated from ideology? What does a commitment to secularism mean for you in this historical context?

TS: The journey, both my own and of CJP, the organisation I represent (which we are building into an all-India civil rights presence) has been revelatory. Before 2002, we had had sporadic experiences within courts of law, trying to ensure substantive justice. One important case, a collective effort to try and ensure prosecution of Bal Thackeray for the hate speech in the Shiv Sena's mouthpiece Saamna in 1992-1993, resulted in a peremptory dismissal by the Bombay High Court. ${ }^{75}$ During the hearing of the petition, judges in the court were visibly scared, asking the counsel for the petitioner, "Will not Bombay burn if the prayer for registration of an FIR against Thackeray for violation of the law is granted?" I was present in court when the senior counsel urging action against hate speech retorted, "My Lord, but Bombay is burning anyways. Maybe this action will stop the arson and killing..." Finally, in September 1994, on the eve of the Shiv Sena being swept into power in the state, a Division Bench of the High Court dismissed the petition, arguing that the hate-filled passages were directed only against 'anti-national Muslims'. Outrage and protests erupted and a public campaign attracted over 35,000 signatures. However, the Supreme Court in its wisdom dismissed the Special Leave Petition without even a hearing!

This dismissal of the petition was a shocking jolt for someone raised in the law, who believed that right would be done by the law. It also meant growth as a journalist, a legal rights activist. Reading and researching into hate speech and Indian law, as I did for a paper for the ILS Law College in Pune, I found that our courts had been timid in their treatment of inciteful speech. Weak links in our democracy? ${ }^{76}$

Then, with the legal actions that we undertook post-Gujarat 2002, as we persisted with me at the forefront, a cold realisation dawned: the more we committed ourselves to deepen the quality of our victories, the harsher would be the vendetta of the state. For the government, for politicians, police officers, men in the administrative services, somehow, writing articles, documentation, presenting papers is or was not

\footnotetext{
75 A Marathi language newspaper published by the Shiv Sena of which Thakeray (the party supremo) was the chief editor. Since July 1991, Saamna had systematically been whipping up a mass frenzy against the Muslim community; a frenzy that reached its peak in January 1993 which resulted in an allout pogrom. A petition was collectively researched and filed — JB De'Souza \& Dilip Thackore v State of Maharashtra. The case was argued by my father, Atul Setalvad. See Teesta Setalvad, 'Anatomy of a Hate Crime - The Bombay Riots Story' (Sabrang, 9 January 2018). https://sabrangindia.in/article/anatomyhate-crime-bombay-riots-story. Accessed 20 June 2020.

76 Teesta Setalvad, 'Paper prepared for the Expert Workshop for the Asia Pacific Organised by OHCHR' (2011). https://www.ohchr.org/Documents/Issues/Expression/ICCPR/Bangkok/TeestaSetalvad.pdf. Accessed 20 June 2020.
} 
a threat: but taking them to court, to hold them legally accountable brought on the wrath of vendetta and abuse.

I have had to seek recourse to anticipatory bail 13 times, all at the hands of vindictive First Information Reports lodged by the Gujarat police and its crime branch. But, the first time when I was targeted during the Best Bakery case retrial in Mumbai with the star witness being induced to slander and abuse me, I recall a hearing in the Supreme Court. A senior lawyer, associated with the then not so powerful right-wing BJP appeared for the star witness, Zahira Shaikh. The nexus was obvious, yet the court was tolerant of the vile abuse he hurled on me personally, my name, my personal choice of a life partner who is born a Muslim etc. Even now, when I remember the incident, I can feel how shaken I was that this was happening, that this could happen, in the Indian Supreme Court. But happen it did. And that day in December 2004 was just the beginning. Thereafter, on multiple occasions, the court was used as a platform for personal abuse and vendetta and remained a silent spectator! Despite these bitter awakenings, a stubborn resolve to persevere has not left me. Maybe one day I will get tired of it all. Not yet, though.

OS: Where does that resolve come from?

TS: Maybe from the realisation that if it could happen to me, born into relative privilege, imagine the fate of an activist who had none of that? And then the feeling - more general - the conviction that the battle one is a part of is a larger one and that fighting it is as critical as a second freedom struggle, if you like. It is sometimes a hopelessly one-sided battle, but it needs to be fought. If India as we know it and was conceived of through the struggles of Adivasis, workers, Dalits, women, and so many more against the brutal exploitation by colonial powers has to be preserved. A republic based on the values of social justice as conceived by Eknath, Namdeo, Tukaram, Basavanna, Narayan Guru, Kabir, Jyotiba-Savitribai Phule, Ambedkar.

We must remember that India managed an amazing feat between 1947-1950 when in spite of and despite the deep fissures caused by the wounds of the Partition related violence, the Constituent Assembly resolved that the Indian Republic would be egalitarian and secular, and Indian nationhood and citizenship would be founded on the basis of a composite nationhood and would not be religion-based.

The first challenge to this came was the assassination of Gandhi on 30 January 1948 by the supremacist right. ${ }^{77}$ Yet, India stood firm. But the spectre of communal violence - the refugee camps of Sikhs in Punjab, Punjabi Hindus in Delhi, Muslims in Bihar, Bengali Hindus in West Bengal — took its toll. We had amazing women like Subhadra Joshi and Mrinalini Sarabhai who, while working in these camps and uncovering brute sexual assaults on women of all three communities, maintained an empathetic secular approach. Secularism for me lies in a commitment to an inheritance of this history of India.

OS: Is strict adherence to the letter and spirit of the Constitution - as the source of the rule of law - a way to advance better state accountability in the aftermath of

\footnotetext{
77 Teesta Setalvad, 'No discussion on who killed Mahatma Gandhi is complete without addressing idea of a Hindu Rashtra' (Sabrang, 28 July 2016). https://sabrangindia.in/article/no-discussion-who-kille d-mahatma-gandhi-complete-without-addressing-idea-hindu-rashtra. Accessed 20 June 2020.
} 
hate crimes or anti-minority violence? I ask this question because the Constitution, it can be argued, is a document that can be both medicine and poison. For example, while it guarantees the right to life under Article 21 on the one hand, on the other, it surreptitiously legitimises torture in police custody under Article 22(3) by suspending the guarantee to protection against arrest and detention for 'enemy aliens' or those booked under special security legislations. ${ }^{78}$ Isn't it a matter of concern that despite the very progressive fundamental rights jurisprudence that the Constitution has enabled, the Supreme Court has never declared any special security legislation that compromises on basic civil liberties to be unconstitutional ${ }^{79}$ How do you perform your role of being a foot soldier of the Constitution when the document carries these contradictions?

TS: It is a difficult and apt question. Yes, while the Constitution is the benchmark today and has been for a few decades since it - and the Republic as we know it came under direct assault, there were earlier happier times when civil libertarians sought to expand the mandate especially as limited by this very Constitution. It is not just Article 22(3) that allows for suspending the guarantee to protection against arrest and detention for 'enemy aliens' or those booked under special security legislations, but other provisions related to the electoral system that has, through the firstpart-the-post system, allowed for gross imbalances and anomalies. Our courts have rarely stood up against repressive legislation, and now it is the UAPA that has been amended with full concurrence between the Congress and BJP. The amendments brought in the worst features of the then repealed Prevention of Terrorism Act into a 1960s law.

Over the past few years, I have also revisited the debate between Ambedkar and Gandhi on the communal award. ${ }^{80}$ Gandhi won, but the systemic issues raised by Ambedkar remain, especially when we see how the majoritarian parties co-opt Dalit leadership in the reserved constituencies. If, as Ambedkar had wished, this determination was left to Dalits and minorities, would India have seen a more democratic leadership emerge from within? Representative governance, in the sense of ensuring the voice of the marginalised within all structures of governance, whether it is the judiciary or the leadership of political parties, is also missing.

So yes, we face this basic contradiction. That while there is the transformative aspect within the Indian Constitution, the men and women who have managed structures and institutions have hegemonised and stymied this potential. Does the answer lie in more struggle, more battles, a further churning? Or something else? The fact remains that after Independence - especially my generation and those older who remained beneficiaries of the egalitarian ethos spawned by the freedom struggle thought, erroneously, that the battle for democracy, equality, fraternity and justice had been permanently won. This battle can only be won when institutions get

\footnotetext{
78 Article 22(1) of the Constitution of India 1949.

${ }^{79}$ Ujjwal Kumar Singh, The State, Democracy and Anti-Terror Laws in India (1st edn, SAGE Publications 2007).

${ }^{80}$ Sujay Biswas, 'Gandhi, Ambedkar and British policy on the communal award' (2018) 5 (1) Studies in People's History 48.
} 
democratised. And when an ideology that organisationally threatens to choke our fundamentals is defeated, and not just electorally.

OS: A ubiquitous symbol of resistance over the last few months in all the antiCAA protests has been the waving of the Indian flag. The anti-CAA protests in India come on the heels of the abrogation of Articles 370 and $35 A$ of the Constitution. ${ }^{81}$ Combined, these two have been the BJP's strongest steps towards achieving a Hindu rashtra. ${ }^{82}$ Do you see any irony in the Indian flag as a symbol of resistance at a time like this because while the flag might be used as a strategic method of reclaiming nationalism from appropriation by Hindutva forces, the flag also reinforces a cartographic imagination of India that includes Kashmir, in effect normalising the occupation? ${ }^{83}$ I would think that it is for this very reason that during the anti-CAA protests at the Gateway of India in Bombay, Mumbai Police singled out Mehak Mirza Prabhu, who was carrying a placard with the slogan 'Free Kashmir' and filed an FIR against her under Section 153 (B) of the IPC for 'assertions prejudicial to national interest. ${ }^{84}$ So even amongst the protestors, an assertion of Kashmiri selfdetermination is exceptionalised as more prejudicial than the questioning of the CAA's exclusionary logic. With regard to student protests on campuses, we have also seen the way the BJP government made it imperative for central universities to fly the tricolour to instil nationalism among students. ${ }^{85}$ What I am asking is, can bad nationalism be countered by good nationalism, or is the idea of nationalism itself something that requires scrutiny?

TS: Naively, one has held on to the belief that there is such a thing as progressive, outward-looking nationalism that can be inclusive. Aware of the emergence of nation-states historically, especially in Europe, one still believed that given the peculiar history of our region where different sorts of oligarchies have ruled (or governed) such conceptualisation was or is possible. Even in Kashmir, while some speak today of the beginning of the occupation the moment when Sheikh Abdullah decided to join the secular union as opposed to the sectarian Dogra king Hari Singh, surely that also accounts for something? But yes, the past six years have seen both realities: the criminals indulging in brute acts of lynching and even the rape of a young girl at Kathua, ${ }^{86}$ seeking to legitimise their barbarism by draping the

\footnotetext{
81 V. Venkatesan, 'Abrogation of Articles 370 and 35A: Assault on the Constitution' (Frontline). https:// frontline.thehindu.com/cover-story/article29048647.ece. Accessed 20 June 2020.

82 Mohsin Alam Bhat, 'Stateless and Hyperlegalized' (The Baffler, 3 January 2020). https://thebaffler .com/logical-revolts/stateless-and-hyperlegalized-alam. Accessed 22 June 2020.

83 Sadan Jha, Reverence, Resistance and Politics of Seeing the Indian National Flag (Cambridge University Press 2016).

84 The Wire Staff, 'Woman Who Held 'Free Kashmir' Poster Booked by Muslim Police' (The Wire, 8 January 2020). https://thewire.in/government/free-kashmir-poster-mumbai-booked. Accessed 20 June 2020 .

85 Anuradha Raman, 'National flag to fly at all Central Universities' (The Hindu, 18 February 2016). https://www.thehindu.com/news/national/hoisting-of-tricolour-to-be-made-mandatory-in-all-centraluniversities/article14086309.ece. Accessed 20 June 2020.

86 Yashwant Thorat, 'As the Kathua Trial Begins, Let Us Remember What Hindu Dharma Really Stands For' (The Wire, 4 June 2018). https://thewire.in/communalism/as-the-kathua-trial-begins-let-us-remem ber-what-hindu-dharma-really-stands-for. Accessed 20 June 2020.
} 
tricolour on bodies of their own dead (criminals) and protesters from among India's unlettered and marginalised reclaiming the tricolour as their claim to Indian citizenship and nationhood, almost defying a hegemonic majoritarian force from its abusive claim on the tricolour. Then there is the fact that the RSS unfurled the tricolour for the first time ever at its Delhi headquarters at Jhandenwala Bagh only in the year 2000 after a minority government controlled by its parliamentary wing, the BJP, first established rule in Delhi. Earlier it had remained abusive of the diversity the flag represented (and the Organiser, the RSS mouthpiece, made several editorial comments on this fact). ${ }^{87}$ So, did the Indian tricolour suddenly become the symbol of Hindutva? Unlikely! It was more like a claim or possession on the idea of the Indian state which it would then twist to its own ideological will.

OS: Do you think that this is the right time to revisit the Communal and Targeted Violence (Access to Justice and Reparations) Bill, 2011? If so, how do you think a law like this needs to be reimagined for current times?

TS: I recall, when the wretched anti-corruption movement led by Anna Hazare captured the imagination of the Indian middle classes in $2010-11,{ }^{88}$ the refrain was that for four decades the Lok Pal Bill was dormant and tabled on the floor of Parliament, now it must be passed! It was passed finally, became a law and the very same middle classes that had risen as one, chose to ignore this utter institutional subversion by the Modi regime. Could it be that with the ideological comfort the middle classes felt with this regime, corruption and money making on a high scale just did not matter anymore? ${ }^{89}$

But to answer the question: Yes, now is the time, ripe as it was after 2002. The Bill of 2011 should not just be revisited but be tabled either as a central law or by some states. But will that happen? I do not think so. The states that are not controlled by the BJP-RSS are still hanging by a thin ideological thread, their commitment to the fundamentals enshrined in the Indian Constitution are firm but not firm enough to recognise the need to acknowledge the historic debt that India needs to pay its minorities by enacting a special legislation that can hold the district collectorate and the police directly responsible for the outbreak of targeted communal violence.

An interview I did in 1995 with the then director general of the Border Security Force, Vibhuti Narain Rai, for Communalism Combat, ${ }^{90}$ caused ripples. The piece brought to light the existence of an institutional acceptance of the existence of communal bias within the law enforcement arms of the state. However, there has also been resistance to this from the Indian Administrative and Police Services, who are

\footnotetext{
87 Radhika Ramaseshan, 'Flag Sangh did not fly for 52 years' (The Telegraph, 20 February 2016). https ://www.telegraphindia.com/india/flag-sangh-did-not-fly-for-52-years/cid/1515040. Accessed 20 June 2020.

88 Matthew Jenkins, 'Anna Hazare, Liberalisation and the Careers of Corruption in Modern India: 19742011' (2014) 49 (33) Economic and Political Weekly 41.

89 Tommaso Bobbio, 'Never-ending Modi: Hindutva and Gujarati neoliberalism as prelude to all-India premiership?' (2013) (67) Focaal - Journal of Global and Historical Anthropology 123.

90 'No riot can last for more than 24 hours unless the state wants it to continue' (Sabrang, 11 February 1995). https://www.sabrangindia.in/interview/no-riot-can-last-more-24-hours-unless-state-wants-it-conti nue. Accessed 20 June 2020.
} 
loath to be held accountable when the political class has not granted autonomy to the law enforcement structure. So, while the law is much needed, it will take a while coming: it will come only when an upsurge from among the Indian people demands such a legislation as a matter of their right.

OS: You started your working life as a journalist and have seen from very close quarters the role the profession has played historically in the context of reporting on communal violence, both as a secular voice of conscience as well as one that has the capacity to foment violence. During Gujarat 2002 we saw the news media play an especially partisan role..$^{91}$ And now the circulation of rumor and propaganda as news happens through WhatsApp. ${ }^{92}$ What do you think is the ethical call for the conscientious journalist in these hate-filled times?

TS: While the media, especially commercial television channels (with the exception of one or two) get pilloried, as they must, for their sickening subservience before this government, the plight of the individual journalist, print or electronic, even the stringer in districts, is pathetic today. The ethical call is simple: report fairly, remember the role of the media which is to question, to turn the searchlight on government and its functioning.

But today a frightening nexus between the billionaire, the corporate leader, the media baron and the politician (the Indian Parliament) exists. In an interview I did with veteran journalist P Sainath in September 2014, he described this vividly. ${ }^{93}$ Sainath commented on the complete domination of Indian Parliament by millionaires. These very individuals and their corporate business interests own controlling shares in the media. This is a rare convergence, hitherto unparalleled, that was witnessed in the brazen corporate campaign to spearhead Modi to power in 2014. ${ }^{94}$ There is a stranglehold on free thought, expression, association that is being dangerously constructed by this unholy nexus. The most exacting challenge to this will be the re-emergence of a genuinely democratic real media.

For instance, if the role and place of the fourth estate (àla the French revolution) is to consistently examine, understand and connect the mechanisms of state and society, should they not in India, a 'democracy'; consistently look at the patterns within our workforce, the conditions, the access to rights, wages, equality, redressal and non-discrimination? However, before even the open onset of the neoliberal

\footnotetext{
91 'Partisan Role of the Media, Gujarat 2002', (Sabrang, 1 December 2002). https://www.sabrangind ia.in/article/partisan-role-media-gujarat-2002. Accessed 20 June 2020; Anuja Jain, "Beaming it live': 24-hour television news, the spectator and the spectacle of the 2002 Gujarat carnage' (2010) 8 (2) South Asian Popular Culture 163.

${ }^{92}$ Rahul Mukherjee, 'Mobile witnessing on WhatsApp: Vigilante virality and the anatomy of mob lynching' (2020) 18 (1) South Asian Popular Culture 70; LSE Department of Media and Communications, WhatsApp Vigilantes: An exploration of citizen reception and circulation of WhatsApp misinformation linked to mob violence in India (2019). http://www.lse.ac.uk/media-and-communications/assets/ documents/research/projects/WhatsApp-Misinformation-Report.pdf. Accessed 20 June 2020.

${ }^{93}$ Teesta Setalvad, 'Transcript of P Sainath's Interview with Communalism Combat - Hillele TV' (Sabrang). https://www.sabrang.com/cc/ccinterviews/psainathtranscript.htm. Accessed 20 June 2020.

${ }^{94}$ Arvind Rajagopal, 'On Media and Politics in India: An Interview with Paranjoy Guha Thakurta' (2016) 40 (1) South Asia: Journal of South Asian Studies 175.
} 
agenda, ${ }^{95}$ newspapers had 'dropped' coverage of the labour/ workers beat $!^{96}$ Why? Because that inconvenienced the ownership of newspaper capital? Now, a vast section of Indian workers are in the unorganised sector and we have little or poor mapping of that sector: experts and academics have some figures but governments do not and the media has no understanding how the construction industry works, how the artisan labour class lives, leave alone issues of exploitation etc.

The media within a democracy needs to look and shape various sectors: for years we have asked for a Rural Beat/Agricultural Beat! Should not caste be looked at; and gender too? Society and families? How much does the Indian middle class spend on itself - food, clothes and weddings? The absence of any structural interrogations by our media have made it more and more episode and sensational events driven: hence the absence of an in-depth or nuanced understanding or analysis of where Indian democracy is heading, in terms of access to rights and the widening of rights vis-avis those who hold control of resources and power. We now have the strange reality of journalism schools opening and yet many of us feel that we, who trained and learned on the beat, understand the real ethics and values of the profession better.

OS: I want to end on a note, even if naively, that offers some possibility of hope in these grim times. Of the many projects that your organisation CJP runs, one of the most significant ones is Khoj (which in English would mean a searching journey). I particularly consider Khoj to be a really important project because it attempts to intervene at the school level by talking to students about India's secular and syncretic histories; and treating students not as empty vessels to be filled with information that passes of as education, but as citizens with a critical awareness of their surroundings. The significance of such a project is in its attempts to address the roots of prejudice that are part of everyday spaces like families and schools where children spend most of their time learning lessons in hate that are taught to them in the most benign and insidious of ways by parents and teachers. Two recent incidents in Karnataka, of an RSS-run school re-enacting the demolition of the Babri Masjid in a celebratory way, ${ }^{97}$ and a parent and school authorities being booked for sedition in another where students put up a play on the anti-CAA protests, ${ }^{98}$ makes a project like Khoj even more relevant for our times. Of course, we must also remember the long-term and ongoing Hindutva agenda of the saffronisation of education

\footnotetext{
95 Sukumar Muralidharan, Freedom, Civility, Commerce: Contemporary media and the public (Three Essays Collective 2018).

96 Monobina Gupta, 'Rough Edges: The Vanishing Tribe of Labour Reporters' (The Wire, 31 January 2018). https://thewire.in/government/rough-edges-the-vanished-tribe-of-labour-reporters. Accessed 20 June 2020; Naren Singh, 'Media's Indifference to Labour Issues is Muzzling the Already Vanishing Voices of Workers' (The Wire, 25 November 2017). https://thewire.in/economy/labour-laws-worke rs-protest-media. Accessed 20 June 2020.

97 The Wire Staff, 'Teach Hate Young: RSS Leader's School Gets Kids to Re-Enact Babri Demolition' (The Wire, 16 December 2019). https://thewire.in/communalism/rss-run-school-makes-children-re-enact -babri-masjid-demolition. Accessed 20 June 2020.

98 Sukanya Shantha, 'Sedition' for School Play on CAA: Student's Dialogue 'Insult to PM'; Parent, Official Arrested' (The Wire, 30 January 2020). https://thewire.in/government/bidar-karnataka-anti-caaplay-school-sedition. Accessed 20 June 2020.
} 
as a background to this. ${ }^{99}$ Can you please tell us about the project and how you see working with school students can be an important way to advance our constitutional commitment to secularism?

TS: Khoj was born out of the fires of the Bombay violence of 1992-1993. ${ }^{100}$ As I traversed my city as a journalist (then with the Business India magazine), I saw how the pernicious ideology of othering had infected even our schools and classes. Muslim students, who came back to school after weeks, sometimes and had to face comments like: 'Why have you not left for Pakistan?'

Something was horribly wrong. Despite us having been a secular republic since 1950, despite our school textbooks of history and civics having the Preamble printed in the first few pages, and the young being made to memorise it, egalitarianism and non-discrimination are not the values we were imbibing. Can you teach equality and non-discrimination without addressing existing inequality? Do we discuss caste exclusion in our classrooms, gender disparity, how families and society treat the girl child? Social studies surely must deal with these aspects, must inculcate a sense of constitutional values in the young learner. That is how the Khoj journey began and a multi-module curriculum was developed. It is still a much-valued exercise and intervention often becoming the victim of political calculations. ${ }^{101}$

We do some pretty interesting things in Khoj. A 'self-portrait module' that draws out an image of the young person, her or his likes or dislikes (in terms of emotions, feelings, thoughts and convictions). ${ }^{102}$ This leads on to a 'problem solving session' that is actually the beginning of a dialogue between young learners, their teachers and their parents. In the first session fascinating issues/ questions emerge: a young girl demanding 'Why is my brother's birthday celebrated with greater fanfare than mine?'; another young learner asking, 'Why do adults not listen?'; or 'Why is shouting or beating the adult way of dealing?'; or 'Why India and Pakistan cannot be friends?'

Reasoning, dialogue, questioning is the essence of the Khoj approach. To always allow for questions between the 'teacher' and the 'taught.' We do teacher training workshops when teachers - sometimes reluctant to open the doors to this approach - say, 'But you are allowing for a very noisy classroom!' To which our response is, 'yes but it's the right kind of noise.'

Bringing in caste into the class draws fiercely honest responses because young people are honest. They will share stories of how 'their' building in a posh Mumbai locality 'discriminates' against the Dalit woman who cleans the toilets in all the

\footnotetext{
99 Hiren Gohain, 'On Saffronisation of Education' (2002) 37 (46) Economic and Political Weekly 4597; Suresh Bhat, Resisting Saffronisation of Textbooks: Karnataka's Success Story' (Sabrang, 20 February 2018). https://sabrangindia.in/article/resisting-saffronisation-textbooks-karnatakas-success-story. Accessed 20 June 2020.

100 CJP Team, 'Khoj: Discover a New Approach to Education' (CJP, 14 February 2019). https://cjp.org. in/khoj-discover-a-new-approach-to-education/. Accessed 20 June 2020.

101 CJP Team, 'Teesta Setalvad all set to face another Challenge' (CJP, 13 July 2018). https://cjp.org.in/ teesta-setalvad-all-set-to-face-yet-another-challenge/. Accessed 20 June 2020.

102 CJP Team, 'Khoj: Self Portrait and Problem Solving' (CJP, 29 October 2018). https://cjp.org.in/khojself-portrait-and-problem-solving/. Accessed 20 June 2020.
} 
flats. Through this sharing, a questioning begins: the questions are taken back home and brought back into the class, and that cycle of inquiry continues.

How do we create spaces that celebrate India's pluralism and diversity? We have this fascinating module where we sort of train young minds into history-telling: exploring and investigating the migratory histories of their families through family accounts, interviews, other details. Carried out over a period of some months, as the research is shared, the classroom suddenly opens up into a myriad colours and diversities! ${ }^{103}$

We soldier on and the young minds that go through three years of the intervention, we believe, do develop a different approach to history and the social sciences. Khoj teaches children not what to think - but how to think. To ask questions of the adult world, to question the images thrown at us by an unthinking and value-less media and to stand tall through this questioning. Indian families and Indian society are prejudiced into believing that the young cannot deal with conflict when in fact they are navigating domestic violence, gender disparity, caste and communal conflict every day of their lives. The reality of poverty too is ever present. So, give an opportunity to the young, tell teachers and schools that for 13 years of the child's life a constitutionally grounded civic education is what we owe the young, and see what a difference we can make.

OS: Your closing thoughts remind me of a well-known quote, almost talismanic in spirit, by the Welsh Marxist theorist and cultural critic Raymond Williams: 'To be truly radical is to make hope possible rather than despair convincing. ${ }^{104}$ Your life and work are inspiring embodiments of this spirit. Thank you, Teesta, for your thoughts and words. It is possibly appropriate that we dedicate this conversation to the memory of Justice Hosbet Suresh (who died on 11 June 2020), a member of the Concerned Citizens Tribunal's jury and an individual whose expemplary commitment to human rights, secularism, and Constitutional guarantees against state repression will continue to be a motivating force for us through these dark and despairing times.

Acknowledgements I thank Arun Sagar for his feedback on the initial set of questions that I had drafted and his overall engagement with the interview. Thanks also to Mohsin Alam Bhat for the conversations that helped give shape to the introduction.

Publisher's Note Springer Nature remains neutral with regard to jurisdictional claims in published maps and institutional affiliations.

\footnotetext{
103 CJP Team, 'Khoj: Maps and Personal Histories' (CJP, 18 December 2018). https://cjp.org.in/khojmaps-and-personal-histories/. Accessed 20 June 2020.

104 Raymond Williams, Resources of Hope: Culture, Democracy, Socialism (Verso 1988).
} 